\title{
Severe primary hypothyroidism in an apparently asymptomatic 19-year-old woman: a case report
}

\author{
Rania Dannan ${ }^{*}$ (D), Sulaiman Hajji ${ }^{2}$ and Khaled Aljenaee ${ }^{2}$
}

\begin{abstract}
Background: Hypothyroidism is diagnosed on the basis of laboratory tests because of the lack of specificity of the typical clinical manifestations. There is conflicting evidence on screening for hypothyroidism.

Case presentation: We report a case of an apparently healthy 19-year-old Kuwaiti woman referred to our clinic with an incidental finding of extremely high thyroid-stimulating hormone (TSH), tested at the patient's insistence as she had a strong family history of hypothyroidism. Despite no stated complaints, the patient presented typical symptoms and signs of hypothyroidism on evaluation. Thyroid function testing was repeated by using different assays, with similar results; ultrasound imaging of the thyroid showed a typical picture of thyroiditis. Treatment with levothyroxine alleviated symptoms and the patient later became biochemically euthyroid on treatment.

Conclusion: There is controversy regarding screening asymptomatic individuals for hypothyroidism; therefore, it is important to maintain a high index of suspicion when presented with mild signs and symptoms of hypothyroidism especially with certain ethnic groups, as they may be free of the classical symptoms of disease.
\end{abstract}

Keywords: Hypothyroidism, TSH, Asymptomatic, Screening, Case report

\section{Background}

We report a case of an apparently healthy 19-year-old Kuwaiti woman referred to our clinic with an incidental finding of extremely high thyroid-stimulating hormone (TSH), tested at the patient's insistence as she had a strong family history of hypothyroidism. Despite no stated complaints, the patient presented typical symptoms and signs of hypothyroidism on evaluation. This raised the question of who should be screened for hypothyroidism. Screening for hypothyroidism refers to the measurement of thyroid function in asymptomatic populations who are at high risk of having thyroid disease, or patients who have mild, nonspecific symptoms, such as tiredness. Here, we summarize the conflicting evidence

\footnotetext{
*Correspondence: rania_dannan@hotmail.com

${ }^{1}$ Kuwaiti Board of Internal Medicine, Ahmadi, Kuwait

Full list of author information is available at the end of the article
}

regarding screening for hypothyroidism, and emphasize the importance of maintaining a high index of suspicion for hypothyroidism even when presented with mild signs and symptoms.

\section{Case report}

A previously healthy, seemingly asymptomatic 19-year-old woman was referred to us by her general practitioner because of an extremely high TSH level of $1099 \mathrm{mlU} / \mathrm{L}$, detected on random testing at the patient's request because of her family's history of autoimmune thyroid disease. The patient reported fatigue with excessive sleepiness lasting more than 14 hours per day, depressed mood, inexplicable weight gain, decreased appetite, hair loss, constipation, and menorrhagia, all indicative of a hypothyroid state. There was no history of chronic medical conditions or regular medication use, although the patient reported the use 
of over-the-counter paracetamol for headaches and dysmenorrhea. Physical examination showed normal vital parameters (weight $72 \mathrm{~kg}$; height $160 \mathrm{~cm}$; blood pressure 124/80 $\mathrm{mmHg}$; pulse $56 \mathrm{bpm}$ ) and classical signs of hypothyroidism: periorbital puffiness and loss of outer third of her eyebrows and dry skin that was not coarse. Neck examination showed no scars and upward thyroid movement with deglutition, a smooth palpable goiter without nodules, and no palpable lymph nodes. Lower limb tone and power were intact despite slow relaxation of ankle reflexes.

Laboratory findings from before and after treatment initiation are presented in Table 1 . At the baseline in April 2019, the patient's TSH was $1099 \mathrm{mlU} / \mathrm{L}$ (Roche assay) and free thyroxin (T4) was $0.7 \mathrm{pmol} / \mathrm{L}$; the TSH level was retested in a Siemens assay, with a similar result (TSH $991 \mathrm{mlU} / \mathrm{L})$. A subsequent anti-thyroid peroxidase (anti-TPO) antibodies test showed high levels $(42 \mathrm{lU} / \mathrm{mL})$. Complete blood count, renal function, liver enzymes, and lipid profile were tested; the hemoglobin level was $10 \mathrm{~g} / \mathrm{dL}$, with a microcytic hypochromic picture, most likely due to iron-deficiency anemia because the ferritin level was $6 \mathrm{ng} / \mathrm{mL}$. The lipid profile showed dyslipidemia (total cholesterol $6.50 \mathrm{mmol} / \mathrm{L}$, low-density lipoprotein $4.09 \mathrm{mmol} / \mathrm{L}$, triglycerides $1.56 \mathrm{mmol} / \mathrm{L})$. Renal function was normal. Ultrasound imaging of the thyroid showed diffuse cystic changes replacing much of the normal thyroid tissue with a "Swiss cheese" appearance (Fig. 1). The patient was started on levothyroxine in April 2019, and subsequent TSH and free T4 tested in December 2019 were $2.320 \mathrm{mIU} / \mathrm{L}$ and $17.5 \mathrm{pmol} / \mathrm{L}$, respectively; symptom resolution was noted after a few weeks on levothyroxine $(100 \mu \mathrm{g})$ supplementation, and the patient became biochemically euthyroid after 6 months.

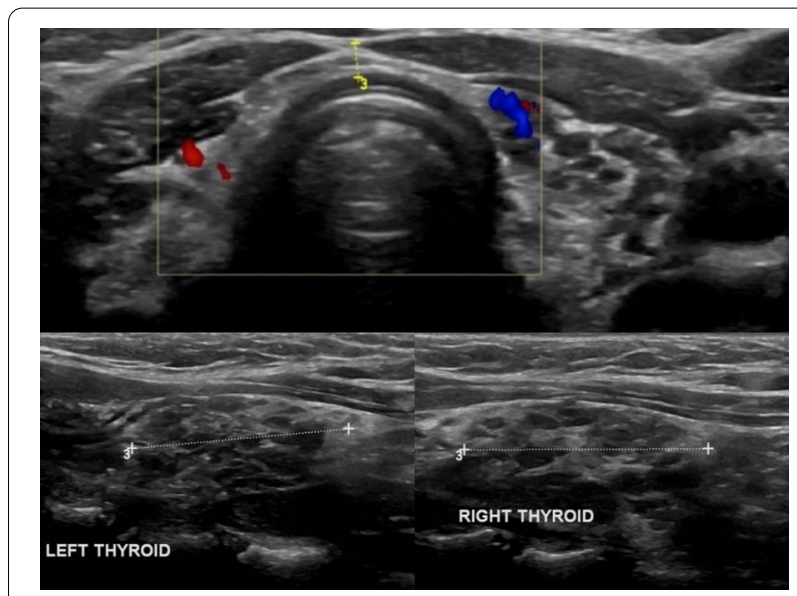

Fig. 1 Ultrasound of the thyroid showing diffuse cystic changes replacing much of the normal thyroid tissue with a "Swiss cheese" appearance

\section{Discussion}

Hypothyroidism is a disorder of thyroid hormone deficiency that affects $0.2-5.3 \%$ of Europeans and $0.3-3.7 \%$ of Americans [1]. Clinical manifestations vary by patient age as well as the duration and severity of thyroid hormone deficiency. Therefore, a definite diagnosis is primarily made on the basis of biochemical testing [2]. There is an ongoing debate about the optimal normal ranges of TSH and T4. A TSH level higher than 4.2-4.5 mlU/L and a free T4 less than $10 \mathrm{pmol} / \mathrm{L}$ confirms hypothyroidism [3]. Therapy aims to supplement thyroxine to alleviate signs and symptoms of hypothyroidism, and to normalize serum thyrotropin without overtreatment [2].

In younger populations, typical symptoms of hypothyroidism are usually present and can facilitate diagnosis, whereas a diagnosis in the elderly is difficult because of

Table 1 Laboratory results

\begin{tabular}{|c|c|c|c|}
\hline & Reference ranges & April 2019 & $\begin{array}{l}\text { December } 2019 \\
\text { (on levothyroxine) }\end{array}$ \\
\hline TSH (mIU/L) (Roche assay) & $0.27-4.2$ & 1099 & 2.320 \\
\hline TSH (mIU/L) (Siemens assay) & $0.27-4.2$ & 991 & 2.320 \\
\hline Free T4 (pmol/L) & $12-22$ & 0.7 & 17.5 \\
\hline Anti-TPO antibodies (IU/mL) & $5-34$ & 42.35 & - \\
\hline $\mathrm{Hb}(\mathrm{g} / \mathrm{dL})$ & $120-140$ & 10.5 & - \\
\hline $\mathrm{MCV}(\mathrm{fL})$ & $78-90$ & 79.5 & - \\
\hline Ferritin (ng/mL) & $10-120$ & 6 & - \\
\hline Total cholesterol (mmol/L) & $3.1-5.1$ & 6.50 & - \\
\hline LDL cholesterol (mmol/L) & $1.5-3.84$ & 4.09 & - \\
\hline HDL cholesterol, (mmol/L) & $1.04-1.9$ & 1.69 & - \\
\hline
\end{tabular}

$T S H$ thyroid-stimulating hormone, $T 4$ thyroxin, Anti-TPO anti-thyroid peroxidase, $H b$ hemoglobin, $M C V$ mean corpuscular volume, $L D L$ low-density lipoprotein, $H D L$ high-density lipoprotein 
seemingly asymptomatic presentation and thus necessitates a high index of suspicion in clinicians to predict hypothyroidism [2]. Moreover, symptoms and signs of hypothyroidism vary from person to person depending on age, gender, and origin [4-6]. Table 2 presents the commonest symptoms and signs of patients with hypothyroidism in Saudi Arabia, Oman, and Australia; in all three countries, tiredness, which was documented in $56 \%, 25 \%$, and $84 \%$ of patients, respectively, was the most common presenting symptom [4-6]. Our patient presented with symptom unawareness despite an extremely high TSH level incidentally detected on biochemical testing, but had typical symptoms of hypothyroidism on clinical evaluation. This raises the question of hypothyroidism screening: who should be screened? And when should they be screened?

Screening for hypothyroidism refers to the measurement of thyroid function in asymptomatic populations who are at high risk of having thyroid disease, or patients who have mild, nonspecific symptoms, such as tiredness. Screening is carried out by measuring serum TSH levels [6], but there are conflicting recommendations on screening. The American Thyroid Association (ATA) recommends screening for hypothyroidism in all

\begin{tabular}{llll}
$\begin{array}{l}\text { Table } 2 \text { Frequency } \\
\text { with hypothyroidism }\end{array}$ & of & symptoms in patients \\
\hline & $\begin{array}{l}\text { Saudi } \\
\text { Arabia [4] }\end{array}$ & Oman [4] & Australia [5] \\
& &
\end{tabular}

\begin{tabular}{llll}
\hline Symptoms & & & \\
Tiredness & 56 & 25 & 84 \\
Cold intolerance & 38 & - & 59 \\
Constipation & 36 & 20 & 40 \\
Weight gain & 36 & 10 & 38 \\
Menstrual disturbances & 36 & 3 & 58 \\
Hair loss & 10 & - & 44 \\
Decreased sweating & 1 & - & 34 \\
Hoarseness & 31 & - & 55 \\
Sleepiness & 14 & - & 40 \\
Coarse hair & 11 & - & 40 \\
Dry skin & 35 & 10 & - \\
Depression & 11 & - & - \\
Signs & & & \\
Coarse skin & 53 & - & 72 \\
Delayed reflex relaxation & 32 & - & - \\
Goiter & 24 & 10 & 21 \\
Periorbital puffiness & 17 & - & 40 \\
Slow movements & 11 & - & 44 \\
Bradycardia & 6 & - & - \\
Slow speech & 5 & - & 48 \\
Lower limb edema & 3 & 3 & - \\
\hline
\end{tabular}

adults 35 years and older every 5 years and in certain high-risk individuals [6]. However, the US Preventative Task Force (USPTF) found insufficient evidence for screening of thyroid dysfunction and emphasizes the uncertainties surrounding potential clinical benefits [7]. Similarly, the Royal College of Physicians in London found no justification for screening for hypothyroidism even in the elderly and individuals with a strong family history of thyroid disease [8]. Exceptions include screening of newborn babies for congenital hypothyroidism and patients with previous thyroid surgery or radioactive iodine treatment as well as patients receiving long-term lithium or amiodarone therapy [8]. There are no strong recommendations for screening of the non-pregnant asymptomatic population for hypothyroidism. Therefore, many asymptomatic patients with overt hypothyroidism could remain undiagnosed and untreated.

\section{Conclusion}

Our 19-year-old patient presented to the clinic with no complaints, but further assessment revealed typical signs and symptoms of hypothyroidism and a TSH level higher than $1000 \mathrm{mlU} / \mathrm{L}$. All symptomatic patients should be evaluated for hypothyroidism, but screening of asymptomatic individuals is controversial and not recommended by certain organizations. This report is presented to recommend a lowering of the screening threshold for hypothyroidism and to motivate physicians to boost their index of suspicion to diagnose the disease, especially with certain ethnic groups, as they may be free of the classical symptoms so severe hypothyroidism can be missed.

\footnotetext{
Abbreviations

Anti-TPO: Anti-thyroid peroxidase; ATA: American Thyroid Association; Hb: Hemoglobin; HDL: High-density lipoprotein; LDL: Low-density lipoprotein; MCV: Mean corpuscular volume; T4: Thyroxin; TSH: Thyroid-stimulating hormone; USPTF: The United States Preventive Services Task Force.

Acknowledgements

Not applicable.

Authors' contributions

$\mathrm{RD}$ was responsible for the literature review and writing of the article and is the corresponding author; SH edited the manuscript and gained consent from the patient; $\mathrm{KJ}$ supplied most of the patient information and images. All authors read and approved the final manuscript.

Funding

Not applicable.

Availability of data and materials

Data sharing not applicable to this article as no datasets were generated or analyzed during the current study.

Ethics approval and consent to participate

Not applicable.
} 


\section{Consent for publication}

Written informed consent was obtained from the patient for publication of this case report and any accompanying images. A copy of the written consent is available for review by the Editor-in-Chief of this journal.

\section{Competing interests}

The authors declare that they have no competing interests.

\section{Author details}

${ }^{1}$ Kuwaiti Board of Internal Medicine, Ahmadi, Kuwait. ${ }^{2}$ Al-Adan Hospital, Kuwait City, Kuwait.

Received: 21 November 2020 Accepted: 11 January 2021

Published online: 03 March 2021

\section{References}

1. Taylor PN, Albrecht D, Scholz A, et al. Global epidemiology of hyperthyroidism and hypothyroidism. Nat Rev Endocrinol. 2018;14(5):301-16.

2. Carle A, Pedersen IB, Knudsen N, et al. Hypothyroid symptoms fail to predict thyroid insufficiency in old people: a population-based case-control study. Am J Med. 2016;129(10):1082-92. https://doi.org/10.1016/j.amjme d.2016.06.013.
3. Lewandowski K. Reference ranges for TSH and thyroid hormones. Thyroid Res. 2015;8(Suppl 1):A17.

4. El-Shafie KT. Clinical presentation of hypothyroidism. J Fam Community Med. 2003;10(1):55-8.

5. Al-Sultan Al, Larbi EB, Magbool G, Karima T, Bagshi M. Clinical presentation of spontaneous primary hypothyroidism in adults. Ann Saudi Med. 1995;15(2):143-7.

6. Oddie TH, Boyd CM, Fisher DA, Hales IB. Incidence of signs and symptoms in thyroid disease. Med J Aust. 1972;2(18):981-6.

7. Garber JR, Cobin RH, Gharib H, et al. Clinical practice guidelines for hypothyroidism in adults: cosponsored by the American Association of Clinical Endocrinologists and the American Thyroid Association. Thyroid. 2012;22(12):1200-35.

8. LeFevre ML, Siu AL, Bibbins-Domingo K, et al. Screening for thyroid dysfunction: US Preventive Services Task Force recommendation statement. Ann Intern Med. 2015;162(9):641-50

9. Vanderpump MPJ, Ahlquist JAO, Franklyn JA, Clayton RN. Consensus statement for good practice and audit measures in the management of hypothyroidism and hyperthyroidism. Br Med J. 1996;313(7056):539-44.

\section{Publisher's Note}

Springer Nature remains neutral with regard to jurisdictional claims in published maps and institutional affiliations.
Ready to submit your research? Choose BMC and benefit from:

- fast, convenient online submission

- thorough peer review by experienced researchers in your field

- rapid publication on acceptance

- support for research data, including large and complex data types

- gold Open Access which fosters wider collaboration and increased citations

- maximum visibility for your research: over $100 \mathrm{M}$ website views per year

At BMC, research is always in progress.

Learn more biomedcentral.com/submissions 